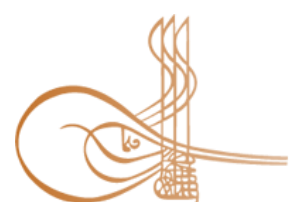

www.turkishstudies.net/social
Turkish Studies - Social Sciences

eISSN: $2667-5617$

Research Article / Araștırma Makalesi

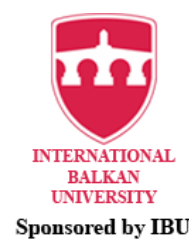

Sponsored by IBU

\title{
Rekreasyon Bölümü Öğrencilerinin Rekreasyon Fayda ve Yaşam Doyum Düzeyleri Arasındaki İlişkinin İncelenmesi
}

\author{
Investigation of the Relationship Between Recreation Benefit and Life Satisfaction Levels of \\ Recreation Department Students
}

\author{
Hayri Akyüz*
}

\begin{abstract}
The ethics committee of the study was taken as a result of the application numbered 2020-SBB0110 at the meeting number 15 dated 03.06.2020. The purpose of this study is to examine the relationship between the leisure benefit and life satisfaction levels of recreation department students and to determine the differentiation status of the recreation benefit and life satisfaction in terms of demographic variables. In the research, "Descriptive (Figurative) and Relational Search Model" was used. The research universe consists of the students of Bartın University Faculty of Sport Sciences Recreation Department. The sample is 146 (58 females, 88 males) people selected from these students by simple random sampling method. The data were collected through "Personal Information Form", "Leisure Benefit Scale (LBS)" and "The Satisfaction with Life Scale (SLS)". The data were analyzed in the program using the SPSS 23.0 package. In the data analysis method, t-Test, ANOVA and Pearson Correlation Analysis were used. Tukey test was also used for multiple comparisons. According to the findings of the research, it was found that the leisure benefit levels of the participants differed according to the variables of class, active sports status, perceived family income and participation in leisure activities. There is a significant relationship between the participants' LBS total score averages and "social benefit" sub-dimension and the age variable. Moreover, it was found that the life satisfaction levels of the participants differed in terms of class variable. On the other hand, no significant relationship was found between the LBS and SLS. As a result, although there was no significant relationship between the leisure benefit and life satisfaction levels of the students, some demographic variables were found to differ in terms of the participants' leisure benefit and life satisfaction levels.
\end{abstract}

Structured Abstract: The ethics committee of the study was taken as a result of the application numbered 2020-SBB-0110 at the meeting number 15 dated 03.06.2020. Apart from the tiring of business life, other compulsory activities in individuals' lifes have made leisure activities an important part of life (Gümüş and Ișık, 2018; Tel and Köksalan, 2008). Regarding the concept of recreation, many researchers make definitions. The concept of recreation can be defined as the whole of activities that individuals participate in their leisure time after fulfilling their responsibilities in their daily lifes. Individuals can engage in some activities for different purposes in their leisure time. Individuals in these activities it is expected to provide benefits to them from different angles.

\footnotetext{
* Dr. Öğr. Üyesi, Bartın Üniversitesi, Spor Bilimleri Fakültesi, Rekreasyon Bölümü Asst. Prof. Dr., Bartin University, Sports Science Faculty, Department of Recreation ORCID 0000-0002-8550-6689

akyuz61@live.com

Cite as/ Atıf: Akyüz, H. (2020). Rekreasyon bölümü öğrencilerinin rekreasyon fayda ve yaşam doyum düzeyleri arasındaki ilişkinin incelenmesi. Turkish Studies - Social, 15(5), 2323-2336.
} https://dx.doi.org/10.47356/TurkishStudies.44285

Received/Geliș: 17 June/Haziran 2020

Accepted/Kabul: 20 August/Ağustos 2020

Copyright (C) INTAC LTD, Turkey

Checked by plagiarism software

Published/Yayın: 30 August/Ağustos 2020

CC BY-NC 4.0 
When the factors affecting life satisfaction are examined, it can be said that some of these factors are related to the benefit that may occur in individuals as a result of participation in recreational activities. As a matter of fact, some of the factors affecting life satisfaction are basically physical, psychological and social factors that can be associated with the physical, psychological and social benefits that individuals will receive as a result of recreational activities. Therefore, the purpose of this study is to examine the relationship between the leisure benefit and life satisfaction levels of recreation department students and to determine the differentiation status of the recreation benefit and life satisfaction in terms of demographic variables.

In the research, "Descriptive (Figurative) and Relational Search Model" was used. The research universe consists of the students of Bartın University Faculty of Sport Sciences Recreation Department. The sample is 146 (58 females, 88 males) people selected from these students by simple random sampling method. The data were collected through "Personal Information Form", "Leisure Benefit Scale (LBS)" and "The Satisfaction with Life Scale (SLS)". The data were analyzed in the program using the SPSS 23.0 package. In the data analysis method, t-Test, ANOVA and Pearson Correlation Analysis were used. Tukey test was also used for multiple comparisons.

In the finding of research, it was found that the leisure benefit levels of the participants differed according to the variables of class, active sports status, perceived family income and participation in leisure activities. In terms of recreation, evaluating individuals' leisure time with sportive activities helps people to decrease their stress levels and be happy while developing their self-confidence. Finding a meaningful difference in favor of individuals with low income can be associated with their social solidarity and sincere friendship. Leisure activities make leisure activities meaningful because they have many features such as being more free and happy, developing their creative powers, benefiting from physical, psychological and social aspects. A low level positive relationship was determined between the participants' LBS total score averages and "social benefit" sub-dimension and the age variable. In line with the findings, it can be said that as the age of the participants increases, the level of benefit they will gain from recreation activities also increases. The fact that the satisfaction of life does not differ can be explained by the fact that the age groups of individuals participate in the research are close to each other. In addition, it was found that the life satisfaction levels of the participants differed in terms of class variable. On the other hand, no significant relationship was found between the LBS and SLS.

Regarding the findings no significant difference was found; the absence of a significant difference regarding gender variable can be explained by the fact that the expectations levels of the participants are similar in terms of benefit from recreational activities. It can be said that the gender variable regarding the life satisfaction finding is not a factor affecting the life satisfaction of the participants. The fact that there is no difference in terms of teaching type variable can be expressed by the similarity of the participants' expectation levels regarding the recreation benefit and life satisfaction scale. Within the scope of the research, it can be said that the daily leisure variable does not have a feature that differentiates the recreation benefit and life satisfaction levels of the participants.

As a result, although there was no significant relationship between the leisure benefit and life satisfaction levels of the students, some demographic variables were found to differ in terms of the participants' leisure benefit and life satisfaction levels.

Keywords: Recreation, Benefit, Life satisfaction, University students, Student.

Öz: Araştırmanın etik kurul onayı 03.06.2020 tarihli ve 15 numaralı toplantıda 2020-SBB-0110 numaralı başvuru sonucunda alınmıştır. Bu araştırmanın amacı rekreasyon bölümü öğrencilerinin rekreasyon fayda ve yaşam doyum düzeyleri arasındaki ilişkinin incelenmesi ve rekreasyon fayda ve yaşam doyumunun demografik değişkenler açısından farklılaşma durumunun belirlenmesidir. Araştırmada "Tanımlayıcı (Betimsel) ve İlişkisel Tarama Modeli” kullanılmıştır. Araştırma evreni, Bartın Üniversitesi Spor Bilimleri Fakültesi Rekreasyon bölümü öğrencilerinden oluşmaktadır. Örneklem, bu öğrencilerden basit tesadüfi örnekleme yöntemiyle seçilen 146 (58 kadın, 88 erkek) kişidir. Veriler "Kişisel Bilgi Formu”, "Rekreasyon Fayda Ölçeği (RFÖ)" ve "Yaşam Doyum Ölçeği (YDÖ)" aracılığıyla toplanmıştır. Veriler SPSS 23.0 paket programı kullanılarak analiz edilmiştir. Veri analiz yönteminde t-Testi, ANOVA ve Pearson Korelasyon Analizi kullanılmıştır. Ayrıca çoklu karşılaştırmalar için Tukey testi kullanılmıştır. Araştırma bulgularına göre, katılımcıların rekerasyon fayda düzeylerinin sınıf, aktif spor yapma durumu, algılanan aile geliri ve boş zaman

Turkish Studies - Social, 15(5) 
etkinliklerine katılım durumu değişkenlerine göre farklılık gösterdiği bulunmuştur. Katılımcıların RFÖ toplam puan ortalamaları ve "sosyal fayda" alt boyutu ile yaş değişkeni arasında anlamlı bir iliş̧i vardır. Dahası, katılımcıların yaşam doyum düzeylerinin sınıf değişkeni açısından farklılık gösterdiği bulunmuştur. Diğer taraftan, RFÖ ile YDÖ arasında anlamlılık gösteren herhangi bir ilişki bulunmamıştır. Sonuç olarak, öğrencilerin rekreasyon fayda ve yaşam doyum düzeyleri arasında anlamlı bir ilişki olmamasına karşın, bazı demografik değişkenlerin katılımcıların rekreasyon fayda ve yaşam doyum düzeyleri açısından farklılık gösterdiği bulunmuştur.

Anahtar Kelimeler: Rekreasyon, Fayda, Yaşam doyumu, Üniversite öğrencileri, Öğrenci.

\section{Giriş}

Teknolojide meydana gelen sürekli gelişim ve değişim, bireylerin çalışma saatlerinde azalmalara yol açmış ve sahip oldukları boş zamanlarda da artış meydana getirmiştir (Karaküçük, 2008; Kılbaş, 2010).

Günümüzde kişiler kendilerini yenilemek adına kendi oluşturdukları stratejiler çerçevesinde boş zamanlara önem vermektedirler (Iwasaki ve Mannell, 2000). İş hayatının yoruculuğunun yanı sıra bireylerin hayatlarındaki diğer zorunlu faaliyetler boş zaman aktivitelerini yaşamın önemli bir parçası haline getirmiştir (Gümüş ve Işık, 2018; Tel ve Köksalan, 2008).

Rekreasyon kavramı ile ilgili olarak birçok araştırmacı tarafından tanımlamalar yapılmaktadır. Rekreasyon kavramı, bireylerin gündelik yaşantıları içerisindeki sorumluluklarını yerine getirdikten sonra boş zamanlarında katılmış oldukları etkinlikler bütünü şeklinde tanımlanabilir. Bireyler sahip oldukları boş zamanlarında farklı amaçlar ile bir takım faaliyetlerde bulunabilirler. Bireylerin içinde bulundukları bu faaliyetlerin onlara farklı açılardan fayda sağlaması beklenmektedir.

Teknoloji ve ekonomideki gelişmeler insanlara eğlence ve boş zamanın kullanımına yönelik rekreasyonel faaliyetlere katılmaları için daha fazla zaman ve firsat vermiştir. Rekreasyonun faydaları, fizyolojik, psikolojik, sosyolojik ve ekonomik açısından ele alınmıştır (Akgül, Ertüzün ve Karaküçük, 2018).

Rekreasyon faydası, boş zaman etkinlikleri sırasında katılımcıların yaşadığı olumlu etkiler şeklinde tanımlanmıştır (Driver, 1990). Rekreasyon yararları sübjektiftir ve bireysel deneyimlere yöneliktir (Kao, 1995). Rekreasyon faydaları üç başlık altında sınıflandırılmıştır: fiziksel, psikolojik ve sosyal faydalar (Hung, 2012). Fiziksel faydalar, fiziksel görünümün korunması, enerji kazanc1, faaliyetler için yeteneklerin geliştirilmesi, düzenli dinlenme, yorgunluğun giderilmesi ve ekstra enerji salınımı anlamına gelmektedir. Psikolojik faydalar, yaşam baskılarından kurtulma, duygusal gevşeme, yaratıcı düşünme, zihin ve bedenin gevşemesi ve yaşamdan zevk alma gibi durumlar ile ilgilidir. Başkaları tarafından dikkate alınacak yeni dostluklar ve ilişkiler kurulması, insanların duygularını anlama ve başkalarının güvenini kazanma durumları da sosyal faydalar arasında sayılabilir (Chen, 2001).

İnsanların yaşam kalite düzeyleri topluluk içerisinde sağlanan boş zaman aktiviteleri ile birlikte olumlu şekilde gelişim ve doyum sağlamaktadır. Bu aktiviteler aracılı̆̆ıyla yaşam doyumu da olumlu yönde artar. Yaşam doyumunu arttıran kişiler rekreasyonel aktiviteleri daha anlamlı ve verimli bir hayat için araç olarak kullanacaktır. Dolayısıyla, kişisel gelişim ve ilerleme, kişinin hem yaşam hem de yaşam doyumuna yönelik mücadelesinde artışa yol açmaktadır (Hemingway, 1996).

Kişilerin hayatlarında mutlu olmaları ve hayatlarının anlamlı olabilmesi adına yaşam doyumu kavramı önem arz etmektedir. Yaşam doyumu geçmişten günümüze bireylerin ilgi odağ 1 olmuş önemli konulardan bir tanesidir (Diener, 1984). Yaşam doyumu, yaşamın bir bütün olarak bireysel bilişsel bir değerlendirmesidir (Shin ve Johnson 1978). 
Diener ve Suh (1997) çalışmalarında yaşam doyumunun bilişsel/yargısal bir süreç ile ilgili olup, kişilerin belirlemiş oldukları ölçütlere göre kendi yaşam kalitelerini genel olarak değerlendirmeleri şeklinde bahsetmişlerdir. Bir başka tanıma göre yaşam doyumu kişinin yaşantısına yönelik inanç ve değerlendirmelerinin bütünü ya da kişinin yaşantısıyla ilgili genel tutumu şeklinde ifade edilmiştir. Rice vd., 1992). Veenhoven (1996)'a göre yaşam doyumu, bütüncül bir şekilde hayatın tüm kalitesindeki pozitif gelişimdeki derece şeklinde tanımlamıştır. Tanımlardan da anlaşılacağ1 üzere yaşam doyumu insan yaşantısının sadece belirli bir bölümü ile ilgili olmayıp tümüyle ilgili olduğunu ortaya koymaktadır.

Kişilerin yaşam doyumunu etkileyen birçok faktör mevcuttur. Bu faktörler günlük hayattan elde edilen mutluluk, hayata yüklenilen anlam, amaca ulaşmak için uyum, olumlu kişisel kimlik, kişinin kendini fiziksel yönden güçlü hissetmesi şeklinde belirtilmektedir (Schmitter, 2003). Tüm bu faktörlerin yanı sıra fiziksel ve ruhsal açıdan sağlam olmak ile birlikte sosyal çevre yaşam doyumunu etkileyen temel faktörlerdendir (Dockery, 2004).

Bütün bu faktörler incelendiğinde bu faktörlerden bazılarının rekreasyonel faaliyetlere katılım sonucunda bireylerde oluşabilecek fayda ile ilişkili olduğu söylenebilir. Nitekim, yaşam doyumunu etkileyen faktörlerden bazıları temelde fiziksel, ruhsal ve sosyal faktörler olması, bireylerin rekreasyonel faaliyetler sonucunda elde edecekleri fiziksel, psikolojik ve sosyal faydalar ile ilişkilendirilebilir. Dolayısıyla bu araştırmada, rekreasyon bölümünde öğrenim gören öğrencilerinin rekreasyon fayda düzeyleri ve yaşam doyum düzeyleri arasındaki ilişkiyi belirlememek amaçlanmıştır.

\section{Yöntem}

\section{Araştırmanın Modeli, Kapsamı, Sınırlılıkları ve Etik Kurul Bilgisi}

- Araştırmada “Tanımlayıcı (Betimsel) ve İlişkisel Tarama Modeli” kullanılmıştır.

- Araştırma 2019-2020 eğitim-öğretim yılı bahar yarıyılı ile sınırlıdır.

- Araştırma kapsamında Bartın Üniversitesi Spor Bilimleri Fakültesi Rekreasyon bölümünde öğrenim gören öğrenciler yer almaktadır.

-Araştırmanın etik kurulu 03.06.2020 tarihli ve 15 numaralı toplantıda 2020-SBB-0110 numaralı başvuru sonucunda alınmıştır.

\section{Araştırmanın Amacı}

Araştırma amacı rekreasyon bölümünde öğrenim gören üniversite öğrencilerinin rekreasyon fayda ve yaşam doyum düzeyleri arasındaki ilişkinin incelenmesi ve rekeasyon fayda ve yaşam doyumun demografik değişkenler açısından farklılaşma durumunun belirlenmesidir.

\section{Veri Toplama Araçları}

Bu başlık atlında üç farklı araç kullanılmıştır. Bunlar; "Kişisel Bilgi Formu”, "Rekreasyon Fayda Ölçeği (RFÖ)" ve "Yaşam Doyumu Ölçeği (YDÖ)"dir.

\section{Kişisel Bilgi Formu}

Form cinsiyet, yaş, sınıf, öğretim türü, aktif spor yapma durumu, algılanan aile geliri, algılanan günlük boş zaman ve boş zaman faaliyetlerine katılım durumu olmak üzere 8 demografik sorudan oluşmaktadır.

\section{Rekreasyon Fayda Ölçeği (RFÖ)}

Ölçeği Ho 2008 yılında tasarlamış; Akgül, Karaküçük ve Ertüzün (2018) ölçeğin geçerlik güvenirlik çalışmasını yapmıştır. Rekreasyon Fayda Ölçeği 3 alt boyut ve 24 maddeden oluşmaktadır. 5'li likert tipinde bir ölçektir. Alt boyutlar (1) Fiziksel, (2) Psikolojik ve (3) Sosyal 
faydalar şeklindedir. Katılımcılar 5'li likert tipindeki ölçeğe (1) Kesinlikle Katılmıyorum - (5) Tamamen Katıliyorum şeklinde yanıt vermektedirler.

\section{Yaşam Doyumu Ölçeği (YDÖ)}

Ölçeği geliștiren Diener, Emmons, Larsen ve Griffin (1985) iken, Türkçe uyarlamasını yapan Dağlı ve Baysal (2016)'dır. Ölçek 5'li likert tipindeki değerlendirme Hiç katılmıyorum (1) ve Tamamen katılıyorum (5) şeklindedir. Ölçek bir alt boyut ve beş maddeden oluşmaktadır.

\section{Araştırmanın Evren ve Örneklemi}

Çalışma evreni Bartın Üniversitesinde 2019-2020 eğitim-öğretim bahar yarıyılında Spor Bilimleri Fakültesi Rekreasyon Bölümündeki öğrencilerden oluşurken, çalışma örneklemini bu öğrencilerden seçilen 146 (58 kadın, 88 erkek) kişi oluşturmaktadır. Örnekleme yöntemi olarak basit tesadüfi örnekleme yöntemi kullanılmıştır.

\section{Veri Analiz Teknikleri}

Güvenirlilik analizlerinde Cronbach's Alpha testinden yararlanılmıştır. Kişisel bilgilere yönelik aritmetik ortalama, standart sapma değerlerin yanı sıra frekans, yüzde değerli analiz edilmiştir. Verilerin farklılaşma durumlarını ortaya koymak için T-testi ve ANOVA, gruplardaki farklılıkları ortaya koymak için TUKEY testi ve değişkenlerdeki ilişkiyi ortaya koymak için Korelasyon analizi kullanılmıştır. Bütün analizlerde anlamlılık değeri $(p<0.05)$ olarak değerlendirilmiştir.

\section{Güvenirlilik}

Tablo 1: Rekreasyon Fayda ve Yaşam Doyumu Ölçeğinin İç Tutarlılık Katsayıları

\begin{tabular}{ccc}
\hline $\begin{array}{c}\text { Ölçeklere İliş̧kin Alt Boyut } \\
\text { ve Toplam Değerler }\end{array}$ & $\begin{array}{c}\text { Madde } \\
\text { Saylları }\end{array}$ & $\begin{array}{c}\text { Cranbach Alpha İç Güvernirlik } \\
\text { Katsayısı }\end{array}$ \\
\hline Fiziksel fayda & 7 madde &, 943 \\
\hline Psikolojik fayda & 8 madde &, 940 \\
\hline Sosyal fayda & 9 madde &, 936 \\
\hline Rekreasyon Fayda Toplam & 24 madde &, 889 \\
\hline Yaşam Doyum Toplam & 5 madde &, 944 \\
\hline
\end{tabular}

Tablo 1'de elde edilen bu değerlerin istatiksel açıdan güvenilir düzeyde olduğu ifade edilebilir (Can, 2014). 


\section{Bulgular}

Tablo 2: Demografik Değerler Tablosu

\begin{tabular}{|c|c|c|}
\hline Cinsiyet & $\mathbf{N}$ & $\%$ \\
\hline Kadın & 58 & 39,7 \\
\hline Erkek & 88 & 60,3 \\
\hline Sinıf & $\mathbf{N}$ & $\%$ \\
\hline 1. $\operatorname{sinif}$ & 35 & 24,0 \\
\hline 2. sinif & 34 & 23,3 \\
\hline 3. sinif & 44 & 30,1 \\
\hline 4. sinif & 33 & 22,6 \\
\hline Öğretim Türü & $\mathbf{N}$ & $\%$ \\
\hline Normal Öğretim & 75 & 51,4 \\
\hline İkinci Öğretim & 71 & 48,6 \\
\hline Aktif Spor Yapma Durumu & $\mathbf{N}$ & $\%$ \\
\hline Evet & 70 & 47,9 \\
\hline Hayır & 76 & 52,1 \\
\hline Algilanan Aile Geliri & $\mathbf{N}$ & $\%$ \\
\hline Düşük & 38 & 26,0 \\
\hline Orta & 54 & 37,0 \\
\hline Yüksek & 54 & 37,0 \\
\hline Algilanan Günlük Boș Zaman & $\mathbf{N}$ & $\%$ \\
\hline Çok az & 32 & 21,9 \\
\hline Orta & 85 & 58,2 \\
\hline Yüksek & 29 & 19,9 \\
\hline Boş Zaman Faaliyetlerine Katılım Durumu & $\mathbf{N}$ & $\%$ \\
\hline Ara sira & 109 & 74,7 \\
\hline Siklıkla & 37 & 25,3 \\
\hline Değişkenler & $x$ & Ss \\
\hline Yaş & 21,924 & 3,089 \\
\hline
\end{tabular}

Tablo 2'ye göre katılımcıların \%39,7'si kadın, \%60,3'ü erkeklerden oluşmaktadır. Katılımcıların 35'ü 1. sınıf, 34'ü 2. sınıf, 44'ü 3. sinıf ve 33'ü 4. sınıf öğrencisidir. Katılımciların öğretim türü incelendiğinde \%51,4’ü normal öğretim, \%48,6's1 ikinci öğretimde öğrenim görmektedir. Katılımcıların 70'inin aktif olarak spor yaptığı, 76'sının ise aktif olarak spor yapmadığ 1 görülmektedir. Öğrencilerin \%26's1 düşük, \%37'si orta ve diğer \%37'si yüksek düzeyde gelire sahip olduklarını belirtmişlerdir. Katılımcıların 32'si algılanan günlük boş zamanlarının çok az düzeyde, 85 'i orta düzeyde ve 29 'ü yüksek düzeyde olduğunu ifade etmiştir. Tabloya bakıldığında katılımcıların \%74,7'si boş zaman faaliyetlerine ara sıra, \%25,3'ü sıklıkla katılmaktadır. Öğrencilerin yaş ortalamaları 21,924 $\pm 3,089$ 'dur.

Tablo 3: Cinsiyet Değişkeni Açısından Rekreasyon Fayda ve Yaşam Doyum Düzeylerine İlişkin

\begin{tabular}{lccccccc}
\multicolumn{7}{c}{ T-testi Tablosu } \\
\hline Alt Boyutlar & Cinsiyet & $\mathbf{N}$ & $\overline{\boldsymbol{x}}$ & $\mathbf{S}$ & $\mathbf{s d}$ & $\mathbf{t}$ & $\mathbf{p}$ \\
\hline Fiziksel fayda & Kadın & 58 & 4,5123 &, 48687 & & & \\
& Erkek & 88 & 4,3977 &, 57243 & 144 & 1,297 &, 197 \\
\hline Psikolojik fayda & Kadın & 58 & 4,5539 &, 53655 & & & \\
& Erkek & 88 & 4,4190 &, 53674 & 144 & 1,486 &, 140 \\
\hline Sosyal fayda & Kadın & 58 & 4,4674 &, 51394 & & & \\
& Erkek & 88 & 4,3270 &, 55090 & 144 & 1,570 &, 119 \\
\hline RFÖ Toplam & Kadın & 58 & 4,5093 &, 46751 & & & \\
& Erkek & 88 & 4,3783 &, 49765 & 144 & 1,615 &, 109 \\
\hline YDÖ Toplam & Kadın & 58 & 3,4862 &, 79482 & & & \\
& Erkek & 88 & 3,7045 &, 72650 & 144 & $-1,680$ &, 096 \\
\hline
\end{tabular}


Tablo 3'e göre katılımcıların cinsiyet değişkeni açısından ölçekler alt boyutları ve toplam puanlarına yönelik anlamlı bir farkl1lık yoktur $(\mathrm{p}>0.05)$.

Tablo 4: Yaş Değişkeni Açısından Rekreasyon Fayda ve Yaşam Doyum Düzeylerine İlişsin Korelasyon Testi Tablosu

\begin{tabular}{cccccc}
\hline & Fiziksel fayda & Psikolojik fayda & Sosyal fayda & RFÖ Toplam & YDÖ Toplam \\
\hline Yaș &, 153 &, 129 &, $216^{*}$ & $186^{*}$ &, 102 \\
\hline
\end{tabular}

Tablo 4'e göre yaş değişkeni ile RFÖ toplam puanları ve "sosyal fayda" alt boyutunda anlamlı bir ilişki vardır $(\mathrm{p}<0.05)$. Tespit edilen bu ilişki düşük düzeyde pozitif yöndedir.

Tablo 5: Sınıf Değişkeni Açısından Rekreasyon Fayda ve Yaşam Doyum Düzeylerine İlişkin ANOVA Testi Tablosu

\begin{tabular}{|c|c|c|c|c|c|c|c|}
\hline Alt Boyutlar & $\begin{array}{c}\text { Varyansın } \\
\text { Kaynağı }\end{array}$ & $\begin{array}{l}\text { Kareler } \\
\text { Toplamı }\end{array}$ & sd & $\begin{array}{c}\text { Kare } \\
\text { Ortalamasi }\end{array}$ & $\mathbf{F}$ & p & $\begin{array}{c}\text { Anlamlı } \\
\text { Farklılık }\end{array}$ \\
\hline \multirow{3}{*}{$\begin{array}{l}\text { Fiziksel } \\
\text { fayda }\end{array}$} & Gruplar aras1 & 1,837 & 3 & ,612 & 2,140 & ,098 & \\
\hline & Gruplar içi & 40,642 & 142 & 286 & & & \\
\hline & Toplam & 42,479 & 145 & & & & \\
\hline \multirow{3}{*}{$\begin{array}{l}\text { Psikolojik } \\
\text { fayda }\end{array}$} & Gruplar aras 1 & ,714 & 3 & 238 & 816 & 487 & \\
\hline & Gruplar içi & 41,395 & 142 & 292 & & & \\
\hline & Toplam & 42,109 & 145 & & & & \\
\hline \multirow{3}{*}{$\begin{array}{l}\text { Sosyal } \\
\text { fayda }\end{array}$} & Gruplar aras1 & 2,799 & 3 & ,933 & 3,367 &, $020^{*}$ & $3>1$ \\
\hline & Gruplar içi & 39,350 & 142 & 277 & & & \\
\hline & Toplam & 42,149 & 145 & & & & \\
\hline \multirow{3}{*}{$\begin{array}{l}\text { RFÖ } \\
\text { Toplam }\end{array}$} & Gruplar arası & 1,486 & 3 & ,495 & 2,124 & ,100 & \\
\hline & Gruplar içi & 33,119 & 142 & 233 & & & \\
\hline & Toplam & 34,605 & 145 & & & & \\
\hline \multirow{3}{*}{$\begin{array}{l}\text { YDÖ } \\
\text { Toplam }\end{array}$} & Gruplar arası & 5,248 & 3 & 1,749 & 3,170 & ,026* & $4>1$ \\
\hline & Gruplar içi & 78,346 & 142 & ,552 & & & \\
\hline & Toplam & 83,594 & 145 & & & & \\
\hline
\end{tabular}

Tablo 5'e göre katılımcıların sınıf değişkeni açısından YDÖ toplam puanlarında ve RFÖ "sosyal fayda" alt boyutunda anlamlı bir farklılık vardır $(\mathrm{p}<0.05)$. Sosyal fayda alt boyutundaki farklılık 3. ve 1. sınıf arasında (3. sınıfın lehine)' dir. YDÖ toplam puanlarda tespit edilen farklılık 4. ve 1 . sinif arasinda (4. sinifin lehine)'dir.

Tablo 6: Öğretim Türü Değişkeni AçısındanRekreasyon Fayda ve Yaşam Doyum Düzeylerine İlișkin T-testi Tablosu

\begin{tabular}{lccccccc}
\hline Alt Boyutlar & Öğretim Türü & $\mathbf{N}$ & $\bar{x}$ & $\mathbf{S}$ & $\mathbf{s d}$ & $\mathbf{t}$ & $\mathbf{p}$ \\
\hline Fiziksel fayda & N.Ö. & 75 & 4,3600 &, 55990 & & & \\
& I.Ö. & 71 & 4,5312 &, 51006 & 144 & $-1,933$ &, 055 \\
\hline Psikolojik fayda & N.Ö. & 75 & 4,4883 &, 50007 & & & \\
& İ.Ö. & 71 & 4,4560 &, 58022 & 144 &, 360 &, 719 \\
\hline Sosyal fayda & N.Ö. & 75 & 4,3096 &, 57945 & & & \\
& I..O. & 71 & 4,4601 &, 48516 & 144 & 1,705 &, 090 \\
\hline RFÖ Toplam & N.Ö. & 75 & 4,3839 &, 49350 & & & \\
& İ.Ö. & 71 & 4,4795 &, 48181 & 144 & $-1,184$ &, 238 \\
\hline YDÖ Toplam & N.Ö. & 75 & 3,6533 &, 68603 & & & \\
& I.Ö. & 71 & 3,5803 &, 83300 & 144 &, 577 &, 565 \\
\hline
\end{tabular}

Tablo 6'ya göre katılımcıların öğretim türü değişkeni açısından ölçekler alt boyutları ve toplam puanlarına yönelik anlamlı bir farklılık yoktur ( $\mathrm{p}>0.05)$. 
Tablo 7: Aktif Spor Yapma Durumu Değişkeni Açısından Rekreasyon Fayda ve Yaşam Doyum Düzeylerine İlişkin T-testi Tablosu

\begin{tabular}{lccccccc}
\hline Alt Boyutlar & Aktif Spor & $\mathbf{N}$ & $\overline{\boldsymbol{x}}$ & $\mathbf{S}$ & $\mathbf{s d}$ & $\mathbf{t}$ & $\mathbf{p}$ \\
\hline Fiziksel fayda & Evet & 70 & 4,5286 &, 53802 & & & \\
& Hayır & 76 & 4,3647 &, 53574 & 144 & 1,843 &, 067 \\
\hline Psikolojik fayda & Evet & 70 & 4,5464 &, 50905 & & & \\
& Hayır & 76 & 4,4046 &, 55971 & 144 & 1,603 &, 111 \\
\hline Sosyal fayda & Evet & 70 & 4,5079 &, 49998 & & & \\
& Hayır & 76 & 4,2675 &, 55130 & 144 & 2,763 &, $006^{*}$ \\
\hline RFÖ Toplam & Evet & 70 & 4,5268 &, 47576 & & & \\
& Hayır & 76 & 4,3416 &, 48629 & 144 & 2,325 &, $021^{*}$ \\
\hline YDÖ Toplam & Evet & 70 & 3,7400 &, 81958 & & & \\
& Hayır & 76 & 3,5053 &, 68545 & 144 & 1,869 &, 064 \\
\hline
\end{tabular}

Tablo 7'ye göre aktif spor yapma durumu değişkeni ile RFÖ toplam puanları ve "sosyal fayda" alt boyutunda anlamlı bir farkl11ık vardır $(\mathrm{p}<0.05)$. Bu anlamlı farklılıklar ortalama değerlere bakıldığında aktif spor yapan katılımcıların lehinedir.

Tablo 8: Algılanan Aile Geliri Değişkeni Açısından Rekreasyon Fayda ve Yaşam Doyum Düzeylerine İlişkin ANOVA Testi Tablosu

\begin{tabular}{|c|c|c|c|c|c|c|c|}
\hline Alt Boyutlar & $\begin{array}{c}\text { Varyansın } \\
\text { Kaynağı }\end{array}$ & $\begin{array}{l}\text { Kareler } \\
\text { Toplamı }\end{array}$ & Sd & $\begin{array}{c}\text { Kare } \\
\text { Ortalamasi }\end{array}$ & $\mathbf{F}$ & $\mathbf{p}$ & $\begin{array}{c}\text { Anlamlı } \\
\text { Farklılık }\end{array}$ \\
\hline \multirow{3}{*}{$\begin{array}{l}\text { Fiziksel } \\
\text { fayda }\end{array}$} & Gruplar arası & 2,010 & 2 & 1,005 & 3,552 & ,031* & \multirow{3}{*}{$\begin{array}{l}\text { Düşük>> } \\
\text { Yüksek }\end{array}$} \\
\hline & Gruplar içi & 40,469 & 143 & ,283 & & & \\
\hline & Toplam & 42,479 & 145 & & & & \\
\hline \multirow{3}{*}{$\begin{array}{l}\text { Psikolojik } \\
\text { fayda }\end{array}$} & Gruplar arası & 4,995 & 2 & 2,498 & 9,623 & ,000* & \multirow{3}{*}{$\begin{array}{c}\text { Düşük> } \\
\text { Yüksek } \\
\text { Orta> } \\
\text { Yüksek }\end{array}$} \\
\hline & Gruplar içi & 37,114 & 143 & ,260 & & & \\
\hline & Toplam & 42,109 & 145 & & & & \\
\hline \multirow[t]{3}{*}{ Sosyal fayda } & Gruplar arası & 4,253 & 2 & 2,126 & 8,023 &, $000^{*}$ & \multirow{3}{*}{$\begin{array}{c}\text { Düşük> } \\
\text { Orta } \\
\text { Düšük> } \\
\text { Yüksek }\end{array}$} \\
\hline & Gruplar içi & 37,896 & 143 &, 265 & & & \\
\hline & Toplam & 42,149 & 145 & & & & \\
\hline \multirow{3}{*}{ RFÖ Toplam } & Gruplar arası & 3,545 & 2 & 1,772 & 8,161 & ,000* & \multirow{3}{*}{$\begin{array}{l}\text { Düşük> } \\
\text { Yüksek }\end{array}$} \\
\hline & Gruplar içi & 31,060 & 143 & ,217 & & & \\
\hline & Toplam & 34,605 & 145 & & & & \\
\hline \multirow{3}{*}{ YDÖ Toplam } & Gruplar arası & 2,593 & 2 & 1,296 & 2,289 & ,105 & \\
\hline & Gruplar içi & 81,001 & 143 & ,566 & & & \\
\hline & Toplam & 83,594 & 145 & & & & \\
\hline
\end{tabular}

Tablo 8'e göre algılanan aile geliri değişkeni ile RFÖ toplam puanları ve bütün alt boyutlarda anlamlı bir farklılık vardır $(\mathrm{p}<0.05)$. Bu anlamlı farklılıklar ortalama değerlere bakıldığında aktif spor yapan katılımcıların lehinedir. Tukey testi sonucunda bu anlamlı farklılıklar, düşük gelir grupları ile nispeten yüksek gelir grupları arasındadır ve düşük gelir grubuna sahip katılımcıların lehinedir. 
Tablo 9: Algılanan Günlük Boş Zaman Değişkeni Açısından Rekreasyon Fayda ve Yaşam Doyum Düzeylerine İlişkin ANOVA Testi Tablosu

\begin{tabular}{|c|c|c|c|c|c|c|}
\hline Alt Boyutlar & $\begin{array}{c}\text { Varyansın } \\
\text { Kaynağı }\end{array}$ & $\begin{array}{l}\text { Kareler } \\
\text { Toplamı }\end{array}$ & sd & $\begin{array}{c}\text { Kare } \\
\text { Ortalaması }\end{array}$ & $\mathbf{F}$ & $\mathbf{p}$ \\
\hline \multirow{3}{*}{ Fiziksel fayda } & Gruplar aras1 & ,195 & 2 & ,098 & ,330 & ,719 \\
\hline & Gruplar içi & 42,284 & 143 & ,296 & & \\
\hline & Toplam & 42,479 & 145 & & & \\
\hline \multirow{3}{*}{ Psikolojik fayda } & Gruplar aras1 & 072 & 2 & ,036 & ,123 & ,885 \\
\hline & Gruplar içi & 42,037 & 143 & ,294 & & \\
\hline & Toplam & 42,109 & 145 & & & \\
\hline \multirow{3}{*}{ Sosyal fayda } & Gruplar aras1 & ,009 & 2 & , 004 & ,015 & ,985 \\
\hline & Gruplar içi & 42,140 & 143 & ,295 & & \\
\hline & Toplam & 42,149 & 145 & & & \\
\hline \multirow{3}{*}{ RFÖ Toplam } & Gruplar aras1 & ,053 & 2 & ,027 & , 110 & ,896 \\
\hline & Gruplar içi & 34,552 & 143 & ,242 & & \\
\hline & Toplam & 34,605 & 145 & & & \\
\hline \multirow{3}{*}{ YDÖ Toplam } & Gruplar aras1 & ,451 & 2 & ,226 & ,388 & 679 \\
\hline & Gruplar içi & 83,142 & 143 &, 581 & & \\
\hline & Toplam & 83,594 & 145 & & & \\
\hline
\end{tabular}

Tablo 9'a göre katılımcıların algılanan günlük boş zaman değişkeni açısından ölçekler alt boyutları ve toplam puanlarına yönelik anlamlı bir farklılık yoktur ( $p>0.05)$.

Tablo 10: Boş Zaman Etkinliklerine Katılım Durumu Değişkeni Açısından Rekreasyon Fayda ve Yaşam Doyum Düzeylerine İlişskin T-testi Tablosu

\begin{tabular}{lccccccc}
\hline Alt Boyutlar & $\begin{array}{c}\text { Katılım } \\
\text { Durumu }\end{array}$ & $\mathbf{N}$ & $\bar{x}$ & $\mathbf{S}$ & $\mathbf{s d}$ & $\mathbf{t}$ & $\mathbf{p}$ \\
\hline Fiziksel fayda & Ara sıra & 109 & 4,3893 &, 52268 & & & \\
& Siklıkla & 37 & 4,6023 &, 57057 & 144 & $-2,004$ &, $038^{*}$ \\
\hline Psikolojik fayda & Ara sıra & 109 & 4,4232 &, 53950 & & & \\
& Siklıkla & 37 & 4,6182 &, 51702 & 144 & $-1,961$ &, $050^{*}$ \\
\hline Sosyal fayda & Ara sıra & 109 & 4,3293 &, 51474 & & & \\
& Siklıkla & 37 & 4,5405 &, 58453 & 144 & 1,956 &, $039^{*}$ \\
\hline RFÖ Toplam & Ara sira & 109 & 4,3781 &, 46756 & & & \\
& Siklıkla & 37 & 4,5845 &, 52222 & 144 & $-2,132$ &, $037^{*}$ \\
\hline YDÖ Toplam & Ara sira & 109 & 3,5890 &, 76392 & & & \\
& Siklikla & 37 & 3,7027 &, 74925 & 144 &,- 794 &, 430 \\
\hline
\end{tabular}

Tablo 10'a göre boş zaman etkinliklerine katılım durumu değişkeni ile RFÖ toplam puanları ve bütün alt boyutlarda anlamlı bir farklılık vardır ve bu anlamlı farklılık sıklıkla boş zaman etkinliklerine katılan öğrencilerin lehinedir $(\mathrm{p}<0.05)$.

Tablo 11: Ölçekler Arası İlişki Açısından Korelasyon Tablosu

\begin{tabular}{lllll}
\hline & Fiziksel fayda & Psikolojik fayda & Sosyal fayda & RFÖ Toplam \\
\hline YDÖ Toplam &,- 078 &,- 077 &, 003 &,- 053 \\
\hline
\end{tabular}

Tablo 11'e göre araştırmada kullanılan iki ölçek arasında hem alt boyut düzeyinde hem de ölçek toplam puanları düzeyinde anlamlı bir farklılık yoktur ( $\mathrm{p}>0.05)$.

\section{Tartışma ve Sonuç}

Katılımcıların \%39,7'si kadın, \%60,3'ü erkektir. Katılımciların 35'ü 1. sinıfta, 34'ü 2. sınıfta, 44'ü 3. sınıfta ve 33’ü 4. Sinıfta öğrenim görmektedir. Katılımciların öğretim türü incelendiğinde \%51,4'ü normal öğretim, \%48,6's1 ikinci öğretimde öğrenim görmektedir. Katılımcıların 70'inin aktif olarak spor yaptığı, 76'sının ise aktif olarak spor yapmadığı görülmektedir. Öğrencilerin \%26's1 düşük, \%37'si orta ve diğer \%37'si yüksek düzeyde gelire sahip 
olduklarını belirtmişlerdir. Katılımcıların 32'si algılanan günlük boş zamanlarının çok az düzeyde, 85 'i orta düzeyde ve 29 'ü yüksek düzeyde olduğunu ifade etmiştir. Diğer taraftan katılımcıların $\% 74,7$ 'si boş zaman faaliyetlerine ara sıra, \%25,3'ü sıklıkla katılmaktadır. Son olarak, katılımcıların yaş ortalama değeri 21,924 $\pm 3,089$ 'dur.

Katılımcıların cinsiyet değişkeni açısından ölçekler alt boyutları ve toplam puanlarına yönelik anlamlı herhangi bir farklılık yoktur ( $p>0.05$ ). Yelpaze ve Yakar (2019) üniversite öğrencileri ile yaptıkları çalışmalarında yaşam doyumunun cinsiyet değişkeni açısından farklılaşmadığını bulgulamıştır. Yalçınkaya (2019) "Üniversite Öğrencilerinin Rekreasyon Fayda Algıları ile Mutluluk Düzeyleri Arasındaki İlişkinin Belirlenmesi” isimli yüksek lisans tez çalışmasında öğrencilerin rekreasyon fayda düzeyleri ile cinsiyet değişkeni arasında bir farklılaşma bulmamıştır. Kocaer (2018) beden eğitimi öğretmenleri ve adayları ile yaptığı çalışmasında cinsiyet değişkeni ve rekreasyon fayda düzeyleri arasında bir farklılık tespit etmemiştir. Karaküçük, Ayyıldız-Turhan, Akgül, Aksın ve Özdemir (2019) oryantiring sporcuları ile yaptıkları çalışmada sporcuların rekreasyon fayda düzeylerinin cinsiyet değişkeni açısından farklılaşmadığını bulmuşlardır. Yaşartürk, Akyüz ve Karataş (2017) rekreasyonel etkinliklere katılan üniversite öğrencileri üzerine yaptıkları çalışmalarında yaşam doyumu ve cinsiyet değişkeni arasında herhangi bir farklılık bulmamıştır. Literatürde yapılan araştırmalarının bulgusu ile çalışma bulgularının hem rekreasyon fayda ölçeği hem de yaşam doyum ölçeği açısından benzerlik gösterdiği görülmektedir. $\mathrm{Bu}$ bulguya ilişkin anlamlı bir farklılık tespit edilmemesi katılımcıların rekreasyonel faaliyetlerden fayda anlamında beklenti düzeylerinin benzer olması ile açıklanabilir. Yaşam doyumu bulgusuna yönelik cinsiyet değişkenin katılımcıların yaşam doyumu etkileyen bir faktör olmadığ 1 söylenebilir.

Bir diğer bulguda yaş değişkeni ile RFÖ toplam puanları ve "sosyal fayda" alt boyutunda anlamlı bir ilişki bulunmuştur $(\mathrm{p}<0.05)$. Tespit edilen bu ilişki düşük düzey pozitif yöndedir $(\mathrm{p}<0.05)$. Bulguya göre katılımcıların yaşı arttıkça rekreasyon faaliyetlerinden elde edecekleri fayda düzeylerinin de arttığı söylenebilir. Kocaer (2018) çalışmasında rekreasyon fayda ile yaş değişkeni arasında bir ilişki bulmamıştır. Kocaer (2018)'in bu bulgusu araştırma bulgusundan farklılık göstermektedir. Diğer taraftan, Yalçınkaya (2019) üniversite öğrencileri üzerine yaptığı yüksek lisans tez çalışmasında öğrencilerin rekreasyon fayda düzeylerinin yaş değişkeni açısından farklılık gösterdiğini bulmuştur. Yalçınkaya (2019)'nın bu bulgusu araştırma bulgusu ile örtüşmektedir. Aydıner (2011) "Üniversite Öğrencilerinin Yaşam Amaçlarını Alt Boyutlarının Genel Öz-Yeterlik Yaşam Doyumu ve Çeşitli Değişkenlere Göre İncelenmesi” başlıklı tez çalışmasında yaşam doyumunun yaşa bağlı olarak farklılaşmadığını tespit etmiştir. Yaşam doyumunun farklılaşmaması araştırmaya katılın bireylerin yaş gruplarının birbirlerine yakın olması ile açıklanabilir.

Katılımcıların sınıf değişkeni açısından YDÖ toplam puanlarında ve RFÖ "sosyal fayda" alt boyutunda anlamlı bir farklılık vardır $(\mathrm{p}<0.05)$. Sosyal fayda alt boyutundaki farklilık 3 . ve 1 . sinıf arasında (3. sınıfin lehine)'dir. YDÖ toplam puanlarda tespit edilen farklılık 4. ve 1. sınıf arasında (4. sınıfın lehine)'dir. Kocaer (2018) yüksek lisans tez çalışmasında sınıf değişkeni ile rekreasyon fayda düzeyleri arasında anlamlı bir farklılık bulmuştur. Kocaer (2018) bu anlamlı farklılığın Rekreasyon Fayda Ölçeği toplam puan ortalamalarında 3. ve 4. sınıf öğrencileri arasında olduğunu ve 4. sinıf öğrencilerinin lehine olduğunu belirtmiştir. Kocaer (2018)'in bu bulgusu araştırma bulgusunu desteklemektedir. Rekreasyon faaliyetleri kişilere birçok fayda sağlamaktadır ve bunlardan bir tanesi de kişilerin sosyalleşmesidir. Bu anlamlı farklılık 4. sınıf öğrencilerinin daha tecrübeli olmaları, sahip oldukları boş zamanları daha farklı kapsamda değerlendirmeleri ve sosyal olmaları ile ilişkilendirilebilir. Diğer yandan, Yelpaze ve Yakar (2019) üniversite öğrencileri ile yaptıkları çalışmalarında yaşam doyumunun sınıf değişkeni açısından farklılaşmadığını bulmuşlardır. Yelpaze ve Yakar (2019)'ın bulgusu araştırma bulgusunu destekler niteliktedir. Yaşam doyumu açısından farklılık bulunmaması sınıf düzeyinin yaşam doyumuna yönelik net bir etkisinin olmaması ile ilişkilendirilebilir. 
Katılımcıların öğretim türü değiş̧keni açısından ölçekler alt boyutları ve toplam puanlarına yönelik anlamlı bir farklılık yoktur ( $p>0.05$ ). Bu bulgu doğrultusunda öğretim türünün katılımcılar açısından her iki ölçek dahilinde farklılık göstermemesi, katılımcıların rekreasyon fayda ve yaşam doyum ölçeğine yönelik beklenti düzeylerinin benzer olması ile ifade edilebilir.

Aktif spor yapma durumu değişkeni ile RFÖ toplam puanları ve "sosyal fayda" alt boyutunda anlamlı bir farklılık vardır $(\mathrm{p}<0.05)$. Bu anlamlı farklılıklar ortalama değerlere bakıldığında aktif spor yapan katılımcıların lehinedir. Çağlayan-Tunç (2019) doktora tez çalışmasında sportif etkinliklere katılım değişkeni ile serbest zaman tatmin ölçeği "sosyal" alt boyutunda sportif etkinliklere aktif olarak katılanların lehine anlamlı bir farklılık bulmuştur. Gökçe (2008) yüksek lisans tezinde spor yapma durumu değișkeninin serbest zaman doyumu bütün alt boyutlar ve toplam puanlar açısından anlamlı düzeyde farklılaştı̆̆ını bulmuştur. Eruzun (2017) yüksek lisans tezinde aktif spor yapma değişkeni ile Boş Zaman Tatmini arasında aktif spor yapan katılımcılar lehine anlamlı bir farklılık bulmuştur. Bütün bu bulguların araştırma bulgusunu desteklediği söylenebilir. Bireylerin sportif etkinlikler ile uğraşması onları kötü alışkanlıklardan uzaklaştırarak sosyal bir ortam içerisinde zaman geçirmelerine olanak sağlar. Kişilerin daha sosyal bir varlık olmasına yardımcı olur. Rekreasyon açısından bireylerin boş zamanlarını sportif faaliyetler ile değerlendirmesi kişilerin stres düzeylerinin azalmasına, mutlu olmalarına yol açarken diğer taraftan kendilerine olan öz güvenlerinin gelişmesine yardımcı olur.

Algılanan aile geliri değişkeni ile RFÖ toplam puanları ve bütün alt boyutlarda anlamlı bir farklılık vardır $(\mathrm{p}<0.05)$. Bu anlamlı farklılıklar ortalama değerlere bakıldığında aktif spor yapan katılımcıların lehinedir. Tukey testi sonucunda bu anlamlı farklılıklar, düşük gelir grupları ile nispeten yüksek gelir grupları arasındadır ve düşük gelir grubuna sahip katılımcıların lehinedir. Düşük gelir grubuna sahip katılımcıların rekreasyon fayda düzeylerinin daha yüksek olması hayatın bazı zamanlarında düşük gelire sahip olan bireylerin toplumsal dayanışma ve samimi arkadaşlıklar kurarak rekreasyonel faaliyetlerde bulunması ile açıklanabilir. Yalçınkaya (2019) "Üniversite Öğrencilerinin Rekreasyon Fayda Algıları ile Mutluluk Düzeyleri Arasındaki İlişkinin Belirlenmesi” isimli yüksek lisans tez çalışmasında öğrencilerin rekreasyon fayda düzeylerinin gelir değişkenine göre farkl11ı gösterdiğini bulmuştur. Benzer şekilde Ayyıldız-Durhan ve Karaküçük (2017) çalışmalarında rekreasyon fayda ölçeğinin gelir değişkeni ile ilişkili olmadığını tespit etmişlerdir. Tüm bu bulgular araştırma bulgusu ile benzerlik göstermektedir. Yaşartürk vd., (2017) rekreasyonel etkinliklere katılan üniversite öğrencileri üzerine yaptıkları çalışmalarında yaşam doyumu ve gelir arasında herhangi bir farklılaşma bulmamışlardır. Yaşartürk vd., (2017)'nin bu bulgusu araştırma bulgusunu desteklemektedir.

Katılımcıların algılanan günlük boş zaman değişkeni açısından ölçekler alt boyutları ve toplam puanlarına yönelik anlamlı bir farklılık yoktur ( $>0.05)$. Araştırma kapsamında günlük boş zaman değişkenin katılımcıların rekreasyon fayda ve yaşam doyum düzeylerini farklılaştıran bir özelliğe sahip olmadığı söylenebilir. Araştırma bulgusu ile benzerlik gösteren çalışmalar incelendiğinde, Kocaer (2018) beden eğitimi öğretmenleri ve adaylarıyla yaptığı çalışmasında katılımcıların rekreasyon fayda düzeylerinin serbest zaman süresi değişkeni açısından farklılık göstermeğini bulmuştur. Karaküçük vd., (2019) oryantiring sporcuları ile yaptıkları çalışmada sporcuların rekreasyon fayda düzeylerinin günlük boş zaman değişkeni açısından farklılaşmadığını bulmuşlardır. Yaşartürk vd., (2017) üniversite öğrencileri üzerine yaptıkları çalışmalarında serbest zaman süresi değişkeni ve yaşam doyum arasında bir farklılık tespit etmemiştir. Algılanan günlük boş zaman değişkeni açısından araştırma anlamlı bir farklılık tespit edimemesi bir düzeyde de katılımcıların serbest zaman doyum düzeyleriyle ilişkilendirilebilir. Bu kapsamda, Yaşartürk, Akyüz ve Gönülateş (2019) üniversite öğrencileri üzerine yaptıkları çalışmasında serbest zaman süresi değişkeni ile serbest zaman doyum düzeyleri karşılaştırıldığında anlamlı bir ilişkiye rastlamamıştır. $\mathrm{Bu}$ durumun tersi sonuçlanan diğer bir çalışmada Yaşartürk (2019) serbest zaman süresi durumuna 
göre serbest zaman doyum düzeyleri karşılaştırıldığında "sosyal" alt boyutunda anlamlı farklılık sonucuna ulaşmıştır.

Boş zaman etkinliklerine katılım durumu değişkeni ile RFÖ toplam puanlanı ve bütün alt boyutlarda anlamlı bir farklılık vardır ve bu anlamlı farklılık sıklıkla boş zaman etkinliklerine katılan öğrencilerin lehinedir $(\mathrm{p}<0.05)$. Boş zaman etkinliklerinin, bireylerin daha özgür ve mutlu olmaları, yaratıcılık güçlerini geliştirmeleri, fiziksel, psikolojik ve sosyal açıdan fayda sağlaması gibi birçok özelliği içinde barındırması bu anlamlı farklılığa gerekçe gösterilebilir. Araştırma bulgusunu destekleyen çalışmalar incelendiğinde, Ağduman (2014) yüksek lisans tez çalışmasında, aktivite sıklığı değişkeni ile serbest zaman tatmin ölçeği arasında boş zaman etkinliklerine daha sık katılan öğrenciler lehine anlamlı bir farklılık tespit etmiştir. Eruzun (2017) yüksek lisans tez çalışmasında haftalık spor yapma sıklıkları değişkeni ile Boş Zaman Tatmini arasında daha sık spor yapan katılımcılar lehine anlamlı bir farklılık bulmuştur.

Araştırmada kullanılan iki ölçek arasındaki ilişki testine yönelik anlamlı bir ilişki bulunmamıştır ( $\mathrm{p}>0.05)$. Her iki ölçek arasında anlamlı bir ilişki tespit edilmemesi yaşam doyumu kavramının anlık olmayıp hayatın bütününü ilgilendirmesi ile gerekçelendirilebilir.

Araştırma sonuçlarına göre, katılımcıların rekerasyon fayda düzeylerinin sınıf, aktif spor yapma durumu, algılanan aile geliri ve boş zaman etkinliklerine katılım durumu değişkenlerine göre farklılık gösterdiği bulunmuştur. Katılımcıların RFÖ toplam puan ortalamaları ve "sosyal fayda" alt boyutu ve yaş değişkeni arasında pozitif yönde bir ilişki bulunmuştur. Ayrıca, katılımcıların yaşam doyum düzeylerinin sınıf değişkeni açısından farklılık gösterdiği bulunmuştur. Diğer taraftan, RFÖ ile YDÖ arasında bir ilişki bulunmamıştır. Sonuç olarak, öğrencilerin rekreasyon fayda ve yaşam doyum düzeyleri arasında bir ilişki bulunmamasına karşın, bazı demografik değişkenlerin katılımcıların rekreasyon fayda ve yaşam doyum düzeyleri açısından farklılık gösterdiği bulunmuştur.

\section{Kaynakça}

Ağduman, F. (2014). Üniversite Öğrencilerinin Boş Zaman Motivasyon ve Tatminlerinin İncelenmesi. Yüksek Lisans Tezi, Atatürk Üniversitesi Sağlık Bilimleri Enstitüsü.

Akgül, B.M., Ertüzün, E. \& Karaküçük, S. (2018). Leisure benefit scale: A study of validity and reliability. Gazi Journal of Physical Education and Sport Sciences, 23(1), 25-34.

Aydıner, B.B. (2011). Üniversite Öğrencilerinin Yaşam Amaçlarının Alt Boyutlarının Genel ÖzYeterlik Yaşam Doyumu ve Çeşitli Değişkenlere Göre İncelenmesi. Yüksek Lisans Tezi, Sakarya Üniversitesi Eğitim Bilimleri Enstitüsü.

Ayyıldız-Turhan, T. \& Karaküçük, S. (2017). Çocuklarıyla Baby Gym aktivitelerine katılan ebeveynlerin rekreasyon fayda düzeylerinin incelenmesi. Gaziantep Üniversitesi Spor Bilimleri Dergisi, 2(4), 43-53.

Can, A. (2014). Spss ile Bilimsel Araştırma Sürecinde Nicel Veri Analizi. (Üçüncü Bask1). Pegem Akademisi.

Chen, Z.Y. (2001). The study of elementary teachers' leisure participation, experience in leisure benefits, and worksatisfaction in Taipei County. National Taiwan Normal University.

Çağlayan-Tunç, A. (2019). Üniversite Öğrencilerinin Kişilik Yapılarının, Zaman Yönetimi ve Serbest Zaman Tatmini ile İlişkisinin İncelenmesi. Doktora Tezi, Gazi Üniversitesi Sağlık Bilimleri Enstitüsü. 
Dağl1, A. \& Baysal, N. (2016). Yaşam doyumu ölçeğinin Türkçe’ye uyarlanması: geçerlik ve güvernirlik çalışması. Electronic Journal of Social Sciences, 15(59), 1250-1262.

Diener, E. \& Suh, E. (1997). Measuring quality of life: Economic, social, and subjective indicators. Social Indicators Research,40, 189-216.

Diener, E. (1984). Subjective well-being. Psychological Bulletin, 95, 542-575.

Diener, E., Emmons, R.A., Larsen, R.J. \& Griffin, S. (1985). The satisfaction with life scale. Journal of Personality Assessment, 49 (1), 71-75.

Dockery, A. (2004). Happiness, Life Satisfaction and The Role of Work: Evidence from Two Australian Surveys, Unpublished Mimeo.

Driver, B.L. (1990). The North American experience in measuring the benefits of leisure. In Proceedings National Workshopon Measurement of Recreation Benefits. Bandoora, Phillip Institute of Technology, 1-57.

Eruzun, C. (2017). Kadınların Spor Etkinliklerine Katılımlarının Boş Zaman Tatmini ve Yaşam Kalitesine Etkilerinin Araştırılması: B-Fit Spor Merkezleri Üyeleri Örneği. Yüksek Lisans Tezi, Bartın Üniversitesi Eğitim Bilimleri Enstitüsü.

Gökçe, H. (2008). Serbest Zaman Doyumunun Yaşam Doyumu ve Sosyo-Demografik Değişkenlerle Illişkisinin İncelenmesi. Yüksek Lisans Tezi, Pamukkale Üniversitesi Sağlik Bilimleri Enstitüsü.

Gümüş, H. \& Işık, Ö. (2018). The relationship of physical activity level, leisure motivation and quality of life in candidate teachers. International Journal of Progressive Education, 14(5), $22-32$.

Hemingway, J.L. (1996). Emancipating leisure: the recovery the freedom in leisure. Journal of Leisure Research, 28(1), 27-43.

Ho, T.K. (2008). A study of leisure attitudes and benefits for senior high school students at PingTung City and country in Taiwan (Unpublished doctoral dissertation). United States Sports Academy.

Hung, H.J. (2012). A study on leisure benefits breaking throughleisure activities. Journal of National Taiwan Normal University, 3(4), 77-92.

Iwasaki, Y. \& Mannell, R.C. (2000). Hierarchical dimensions ofleisure stress coping. Leisure Sciences, 22(3), 163-181.

Kao, C.H. (1995). A three-factor model of leisure benefits. Journal of Outdoor Recreation Study, $8(1), 67-78$.

Karaküçük, S. (2008). Rekreasyon Boş Zaman Değerlendirme. (Altıncı Bask1). Gazi Kitabevi.

Karaküçük, S., Ayyıldız-Turhan, T., Akgül, B.M., Aksın, K. \& Özdemir, A.S. (2019). Oryantiring sporcularında ekosentrik, antroposentrik, antipatik yaklaşımların rekreasyon fayda ile ilişkisi. GEFAD / GUJGEF, 39(3), 1263-1288.

Kılbaş, Ş. (2010). Rekreasyon Boş Zaman Değerlendirme. (Dördüncü Baskı). Ankara: Gazi Kitapevi.

Kocaer, G. (2018). Beden Ĕgitimi ve Spor Öğretmenleri ve Adaylarının Öğretmenlik Mesleğine Yönelik Tutum, Serbest Zaman Ilgilenim ve Rekreasyon Faaliyetlerine Yönelik Fayda Düzeyleri Arasındaki İlişkinin İncelenmesi (Bartın İli Örneği). Yüksek Lisans Tezi, Bartın Üniversitesi Eğitim Bilimleri Enstitüsü. 
Rice, R.W., Frone, M.R. \& McFarlin D.B. (1992). Work-Nonwork conflict and the perceived quality of life, Journal of Organizational Behavior, 13(2), 155-168.

Schmitter, A. C. (2003). Life satisfaction in centenarians residing in long-term care. http://www.mmhc.com/articles/NHM9912/cutillo.html. Erişim Tarihi: 21.04.2013.

Shin, D., \& Johnson, D.M. (1978). Avowed happiness as an overall assessment of the quality of life. Social Indicators Research, 5, 475-492.

Tel, M. \& Köksalan, B. (2008). Öğretim üyelerinin spor etkinliklerinin sosyolojik olarak incelenmesi (Doğu anadolu örneği). Fırat Üniversitesi Sosyal Bilimler Dergisi, 18(1), 261-278.

Veenhoven, R. (1996). Chapter 1 in: Saris, W.E., Veenhoven, R., Scherpenzeel, A.C. \& Bunting B. (Eds.). 'A comparative study of satisfaction with life in Europe. Eotvos University Press, 2, 11-48.

Yalçınkaya, N. (2019). Üniversite Öğrencilerinin Rekreasyon Fayda Algıları Ille Mutluluk Düzeyleri Arasındaki İlişkinin Belirlenmesi. Yüksek Lisans Tezi, Sakarya Uygulamalı Bilimler Üniversitesi Lisansüstü Eğitim Enstitüsü.

Yaşartürk, F. (2019). Analysis of the relationship between the academic self-efficacy and leisure satisfaction levels of university students. Journal of Education and Training Studies, 7(3), $106-115$.

Yaşartürk, F., Akyüz, H. \& Gönülateş, S. (2019). The investigation of the relationship between university students' levels of life quality and leisure satisfaction. Universal Journal of Educational Research, 7(3), 739-745.

Yaşartürk, F., Akyüz, H. \& Karataş, İ. (2017). Rekreatif etkinliklere katılan üniversite öğrencilerinin serbest zamanda sıkılma algısı ile yaşam doyum düzeyleri arasındaki ilişkinin incelenmesi. International Journal of Cultural and Social Studies (IntJCSS), 3(SI), 239-252.

Yelpaze, İ. \& Yakar, L. (2019). Üniversite öğrencilerinin yaşam doyumu ve bilişsel esnekliklerinin incelenmesi. Türk Psikolojik Danışma ve Rehberlik Dergisi, 9(54), 913-935. 